\title{
Perancangan Sistem Informasi Pendukung Keputusan Untuk Menentukan Kelayakan Mahasiswa Tinggal di Luar Asrama (Studi Kasus: Universitas Advent Indonesia)
}

\author{
Rendi Ronaldo*1, Elmor Benedict Wagiu² \\ ${ }^{1,2}$ Fakultas Teknologi Informasi, Universitas Advent Indonesia \\ e-mail: *1rendyronaldo@rocketmail.com, 2elmor@unai.edu
}

\begin{abstract}
Abstrak
Sistem Pendukung keputusan adalah sistem yang dapat memberikan kemampuan dalam pemecahan masalah, sehingga pengguna dari sistem tersebut dapat memilih alternatif keputusan yang terbaik. Dalam pengambilan keputusan tersebut juga banyak hal yang harus diperhatikan agar keputusan yang diambil adalah keputusan yang tepat. Universitas Advent Indonesia sebagai salah satu universitas yang menyediakan asrama sebagai tempat tinggal mahasiswanya. Selain asrama mahasiswa juga dapat memilih untuk tinggal di luar asrama. Untuk dapat tinggal di luar asrama mahasiswa harus mendaftarkan diri dan selanjutnya akan diseleksi oleh Biro Kemahasiswaan. Adapun permasalahan yang dihadapi oleh Biro Kemahasiswaan yaitu adanya kesulitan dalam menentukan keputusan apakah mahasiswa yang mendaftar tersebut layak atau tidak untuk tinggal di luar asrama. Untuk mengatasi permasalahan tersebut maka dirancang sebuah sistem pendukung keputusan untuk menentukan kelayakan mahasiswa tinggal di luar asrama. Adapun persyaratan yang sudah ditentukan untuk dapat tinggal di luar asrama adalah tinggal di rumah dosen, mahasiswa yang telah menikah, di rumah orang tua kandung atau saudara kandung, mahasiswa keperawatan yang sedang mengambil profesi Ners dan mahasiswa tingkat akhir yang tidak memiliki mata kuliah lagi selain skripsi. Penelitian ini menggunakan metode Forward Chaining dan dalam perancangan sistem tersebut akan dibuat berbasis web. Hasil dari penelitian ini dapat digunakan sebagai alat bantu dalam mengambil keputusan untuk menentukan kelayakan mahasiswa tinggal di luar asrama.
\end{abstract}

Kata Kunci: Sistem Informasi, Forward Chaining, Rule-Based

\section{The Design of a Decision Support Information System to Determine the Eligibility of Students to Reside Outside the Dormitory (Case Study : Universitas Advent Indonesia)}

\begin{abstract}
Decision support system is a system that provide problem solving, where the users of the system can choose the best alternative decision. In making the decision there are many things must be considered so that the decision taken is the right one. Universitas Advent Indonesia is one of the universities that provides a dormitory as a residence for the students. Besides dormitories, the students can also reside outside the dormitory. To be able to reside outside, students must register themselves and the Student Affairs Bureau decides who is the student that meet the qualification. There is a problem faced by the Student Affairs Bureau where there is a difficulty to finalize the decision whether students are eligible or not. To occupy the problem, a decision support system is designed to verify the eligibility of students. The requirements that have been decided for the students to be able to reside outside are stay at the lecturer's house, have been married, stay with their parents or their siblings, the nurses students that have taken the professional nurses and the senior students that do not longer have any subject besides thesis. This research used Forward Chaining method and in designing the system the web-based will be employed. The result of this study can be used as a tool in making decision to determine the eligibility of the students to reside outside.
\end{abstract}


Keywords: Information System, Forward Chaining, Rule-Based

\section{Pendahuluan}

Di zaman globalisasi seperti saat ini perkembangan teknologi terjadi dengan sangat cepat, teknologi menjadi salah satu bagian yang sangat penting dan tak terpisahkan dari kehidupan sehari-hari. Universitas Advent Indonesia (UNAI) adalah universitas yang memiliki banyak fasilitas salah satu nya adalah asrama. Mahasiswa di UNAI pada dasar nya di tuntut untuk tinggal di asrama karena pendidikan di UNAI berfokus pada pendidikan karakter dan berdasarkan penelitian yang sudah ada menyatakan bahwa pendidikan asrama sangat berpengaruh terhadap karakter mahasiswa sebesar 93,8\% [1]. Tetapi selain asrama, UNAI juga memberikan pilihan untuk dapat bertempat tinggal di luar asrama. Untuk tinggal di luar asrama, tidak semua mahasiswa dapat diizinkan dan yang dapat memberikan perizinan tersebut adalah Biro Kemahasiswaan. Oleh karena itu bagian Biro Kemahasiswaan UNAI melakukan seleksi yang ketat terhadap mahasiswa Yang berminat untuk tinggal di luar asrama. Bagi mahasiswa yang ingin tinggal di luar asrama terbagi menjadi beberapa jenis dan hanya di izinkan bagi yang tinggal bersama orang tua kandung, tinggal bersama staf/dosen, tinggal bersama saudara kandung, mahasiswa yang sudah menikah, mahasiswa perawat yang sedang mengambil profesi ners, dan mahasiswa tingkat akhir yang tidak memiliki mata kuliah lagi selain skripsi. Selama ini proses seleksi dan pengambilan keputusan dilakukan secara manual yang mengakibatkan terjadi penumpukan antrian mahasiswa, kesenjangan waktu yang panjang dan perizinan juga masih memperhatikan rasa emosional penyeleksi sehingga mahasiswa dan mahasiswi yang melamar tidak terseleksi dengan baik. Oleh karena itu untuk membantu proses seleksi kelayakan mahasiswa tinggal di luar asrama, dibutuhkan sistem pendukung keputusan. Sistem Pendukung Keputusan adalah sebuah sistem berbasis komputer yang interaktif dan dibuat untuk membantu penggunanya dalam proses pengambilan keputusan agar keputusan yang diambil pengguna adalah keputusan yang akurat dan tepat [2].

Melihat penelitian sistem pendukung keputusan dari beberapa peneliti sebelumnya, Sistem Pendukung Keputusan merupakan sistem berbasis komputer yang adaptif, interaktif dan fleksibel yang secara khusus di kembangkan untuk memberikan solusi dari permasalahan manajemen dan membantu dalam meningkatkan kualitas pada saat proses pengambilan keputusan [3]. Dari hasil proses seleksi dengan menggunakan kriteria-kriteria yang ditentukan sistem ini diharapkan dapat memberikan keputusan yang terbaik terhadap permasalahan proses seleksi kelayakan mahasiswa untuk tinggal di luar asrama.

Dalam perancangan sistem pendukung keputusan diperlukan metode untuk mendukung proses pengambilan keputusan tersebut. Salah satu metode yang dapat digunakan adalah Forward Chaining. Metode Forward Chaining adalah metode pelacakan ke depan yang dimulai dari data-data awal yang sudah dikumpulkan yaitu ciri-ciri yang jika diproses akan menuju kepada kesimpulan (goal) [4].

Penelitian tersebut hanya berfokus kepada perancangan sistem pendukung keputusan untuk menentukan kelayakan mahasiswa tinggal di luar asrama dan tidak membahas tentang keamanan informasi, tidak terhubung dengan database Universitas Advent Indonesia dan tidak berfokus pada tampilan sistem. Adapun tujuan yang ingin dicapai dari penelitian ini adalah untuk merancang sebuah sistem pendukung keputusan berbasis web, merancang sebuah sistem pendukung keputusan yang dapat membantu dalam pengambilan keputusan bagi mahasiswa yang ingin tinggal di luar asrama dan membuat laporan hasil penyeleksian secara komputerisasi. 


\section{Metode Penelitian}

\section{Tinjauan Pustaka}

\section{Forward Chaining}

Forward Chaining adalah salah satu metode pengambilan keputusan yang umum digunakan. Proses pencarian dengan metode Forward Chaining dimulai dari kiri ke kanan yaitu dimulai dari premis sampai kepada kesimpulan akhir, metode ini sering disebut data driven di mana pencarian dikendalikan oleh data yang sudah diberikan [5] .

Metode Forward Chaining cocok digunakan jika ada masalah tertentu yang tidak dapat dipecahkan dengan cara perhitungan yang pasti, Intinya adalah menganalisis semua kondisi yang mungkin terjadi dan akan dilakukan penentuan pernyataan untuk setiap kondisi tersebut. Metode Forward Chaining menggunakan himpunan aturan kondisi (if) dan aksi ( Then) untuk mendapatkan suatu kesimpulan. Apabila salah satu aturan tersebut sudah sesuai dengan jawaban dari pengguna, Maka sistem akan memberikan rekomendasi suatu saran yang berupa keputusan.

Pernyataan if dapat digunakan dengan gabungan else atau tanpa gabungan else tergantung dari masalah yang akan dipecahkan. Jika terdapat dua kondisi atau lebih yang terdapat komplementer maka pernyataan if akan diikuti dengan else. Metode tersebut dapat digambarkan dalam bentuk pohon hirarki Forward Chaining. Konsep pohon keputusan adalah proses mengubah data menjadi pohon keputusan atau hirarki [6]. Hal yang penting pada saat pengambilan keputusan adalah pengambilan keputusan itu harus dilakukan secara aktif memilih dan mempertimbangkan alternatif mana yang akan dijadikan keputusan.

Adapun langkah yang perlu dilakukan adalah sebagai berikut :

1. Melakukan identifikasi jaringan hubungan dari setiap komponen-komponen yang ada secara Bersama-sama membentuk masalah yang harus dipecahkan nantinya dengan menggunakan diagram keputusan. Masalah tertentu tersebutlah yang merupakan masalah utama.

2. Merinci masalah utama ke dalam masalah yang lebih kecil

3. Masalah yang sudah terperinci menjadi kecil kemudian dirincikan ke dalam masalah yang lebih kecil lagi, begitu seterusnya sehingga dihasilkan diagram pohon yang bercabang-cabang

Itulah sebabnya pengambilan keputusan tersebut dinamakan diagram pohon [7].

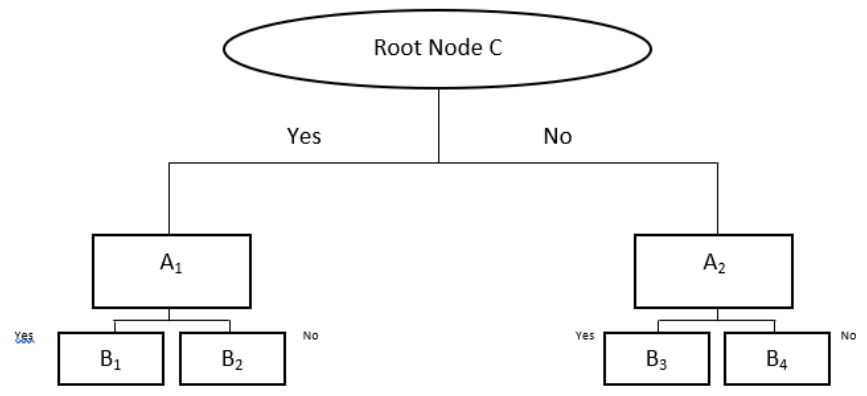

Gambar 8. Contoh Pohon keputusan [8].

Pada pohon keputusan terdapat 3 jenis node:

1. Root Node, adalah node paling atas pada bagian node ini tidak ada input dan tidak mempunyai output

2. Internal Node, Adalah node cabang pada node ini terdapat input dan juga output

3. Leaf node atau terminal node, adalah node yang terakhir hanya memiliki input dan tidak memiliki output. 


\section{Analisa Pendahuluan}

Analisa pendahuluan perlu dilakukan untuk mengetahui permasalahan yang dihadapi oleh Universitas Advent Indonesia Khususnya bagian Biro Kemahasiswaan. Dalam kegiatan analisa ini akan menghasilkan Alternatif, Kriteria dan Rencana rancangan sistem yang didapat dengan cara wawancara dan observasi langsung dengan pihak-pihak yang bersangkutan seperti Wakil Rektor 3 dan Biro Kemahasiswaan.

\section{Strategi Penelitian}

Adapun strategi dalam penelitian ini dilakukan menurut urutan sebagai berikut:

1. Mengumpulkan data tentang persyaratan tinggal di luar asrama

2. Melakukan analisa terhadap data-data yang sudah terkumpul

3. Merancang metode Forward Chaining.

4. Merancang desain user interface sebagai media antara user dan sistem agar dapat berinteraksi

5. Melakukan pengkodean untuk membangun sistem berbasis web.

\section{Penelitian Terdahulu}

Sistem Pendukung keputusan ini memiliki beberapa referensi dari penelitian terdahulu, di mana dari mempelajari penelitian terdahulu tersebut berguna untuk memberikan ide dan masukkan dalam melakukan penelitian ini. Berikut adalah beberapa referensi dari penelitian terdahulu:

Tabel 6 Penelitian Terdahulu

\begin{tabular}{|l|l|l|}
\hline NO & Judul Penelitian & Keterangan \\
\hline $\mathbf{1}$ & $\begin{array}{l}\text { Aplikasi Sistem Pendukung } \\
\text { keputusan Diagnosa Penyakit } \\
\text { Paru-Paru Dengan Metode } \\
\text { Forward Chaining [9] }\end{array}$ & $\begin{array}{l}\text { Sistem yang dikembangkan mampu menelusuri penyakit paru-paru } \\
\text { berdasarkan gejala-gejala yang sudah didefinisikan dan dapat } \\
\text { digunakan masyarakat umum untuk mendeteksi penyakit paru-paru } \\
\text { secara dini sebelum ke dokter. }\end{array}$ \\
\hline $\mathbf{2}$ & $\begin{array}{l}\text { Penentuan Karakteristik } \\
\text { Pengguna Sebagai Pendukung } \\
\text { Keputusan Dalam Memilih } \\
\text { Smartphone Menggunakan } \\
\text { Forward Chaining [10] }\end{array}$ & $\begin{array}{l}\text { Sistem yang dikembangkan menggunakan metode Forward Chaining } \\
\text { yang berbasis pada rule based. Hasil dari perancangan sistem dapat } \\
\text { memberikan rekomendasi atau alternatif keputusan dalam pemilihan } \\
\text { smartphone yang sesuai dengan kebutuhan pengguna. }\end{array}$ \\
\hline $\mathbf{3}$ & $\begin{array}{l}\text { Sistem Pendukung Keputusan } \\
\text { Pemilihan Tanaman Pangan } \\
\text { Menggunakan Metode Forward } \\
\text { Chaining [11] }\end{array}$ & $\begin{array}{l}\text { Sistem yang dikembangkan mampu memberikan informasi berbagai } \\
\text { daftar harga komoditi tanaman pangan, informasi curah hujan, } \\
\text { informasi jenis tanah dan sistem tersebut dapat menentukan pemilihan } \\
\text { tanaman yang tepat untuk ditanam secara akurat. }\end{array}$ \\
\hline
\end{tabular}

\section{Hasil}

\section{Analisis Data}

Dalam proses pemilihan mahasiswa yang layak untuk tinggal di luar asrama, persyaratan adalah data yang dibutuhkan untuk dijadikan acuan dalam pengambilan keputusan. Adapun output yang akan dihasilkan adalah keputusan dari setiap Mahasiswa yang mendaftar apakah Mahasiswa tersebut dapat tinggal di luar asrama atau tidak. Analisis data dilakukan dengan memasukkan data dari hasil observasi dan wawancara berupa alternatif dan kriteria. Data Alternatif adalah pilihan tinggal di luar asrama yang dapat dipilih mahasiswa dan kriteria adalah persyaratan yang harus dipenuhi jika ingin tinggal di luar asrama. Dari pedoman aturan tinggal di luar asrama dan wawancara dengan pihak Biro Kemahasiswaan didapatkan 6 kategori status yang salah satunya harus dipenuhi oleh Mahasiswa yang mendaftar untuk menentukan apakah Mahasiswa tersebut layak tinggal di luar asrama atau tidak seperti pada tabel berikut: 
Tabel 7 Alternatif dan Kriteria untuk tinggal di luar asrama

\begin{tabular}{|c|l|l|}
\hline NO & \multicolumn{1}{|c|}{ Alternatif } & \multicolumn{1}{c|}{ Kriteria } \\
\hline $\mathbf{1}$ & Tinggal di rumah staf/dosen & $\begin{array}{l}\text { Di izinkan hanya 2 orang (sejenis) di setiap keluarga kecuali saudara } \\
\text { kandung dengan menunjukkan kartu keluarga }\end{array}$ \\
\cline { 3 - 3 } & & $\begin{array}{l}\text { Pada semester padat hanya hanya anak staf/dosen yang diijinkan tinggal } \\
\text { di luar asrama }\end{array}$ \\
\hline $\mathbf{2}$ & Married Students & Memiliki surat akta nikah \\
\hline $\mathbf{3}$ & Di rumah orang tua kandung & Berjarak tidak lebih dari 3 km (kecuali untuk warga asli) \\
\hline $\mathbf{4}$ & Profesi Ners & Mahasiswa Keperawatan S1 yang sedang mengambil profesi ners \\
\hline $\mathbf{5}$ & Saudara Kandung & Saudara kandung sesuai dengan kartu keluarga \\
\cline { 3 - 4 } & & Tempat tinggal tidak berjarak lebih dari 3 km \\
\cline { 3 - 4 } & & Sudah bekerja \\
\hline $\mathbf{6}$ & Mahasiswa Skripsi Penuh & Tidak ada Mata Kuliah yang diambil hanya tinggal skripsi penuh \\
\hline
\end{tabular}

\section{Perancangan Forward Chaining}

Dari hasil Analisa terhadap data-data yang sudah dikumpulkan bahwa pemecahan masalah permasalahan penyeleksian Mahasiswa tinggal di luar asrama dapat dilakukan dengan bantuan metode tree. Hasil seleksi mahasiswa didapatkan dari menjawab pertanyaan yang sudah disusun dalam bentuk pohon sebagai berikut:

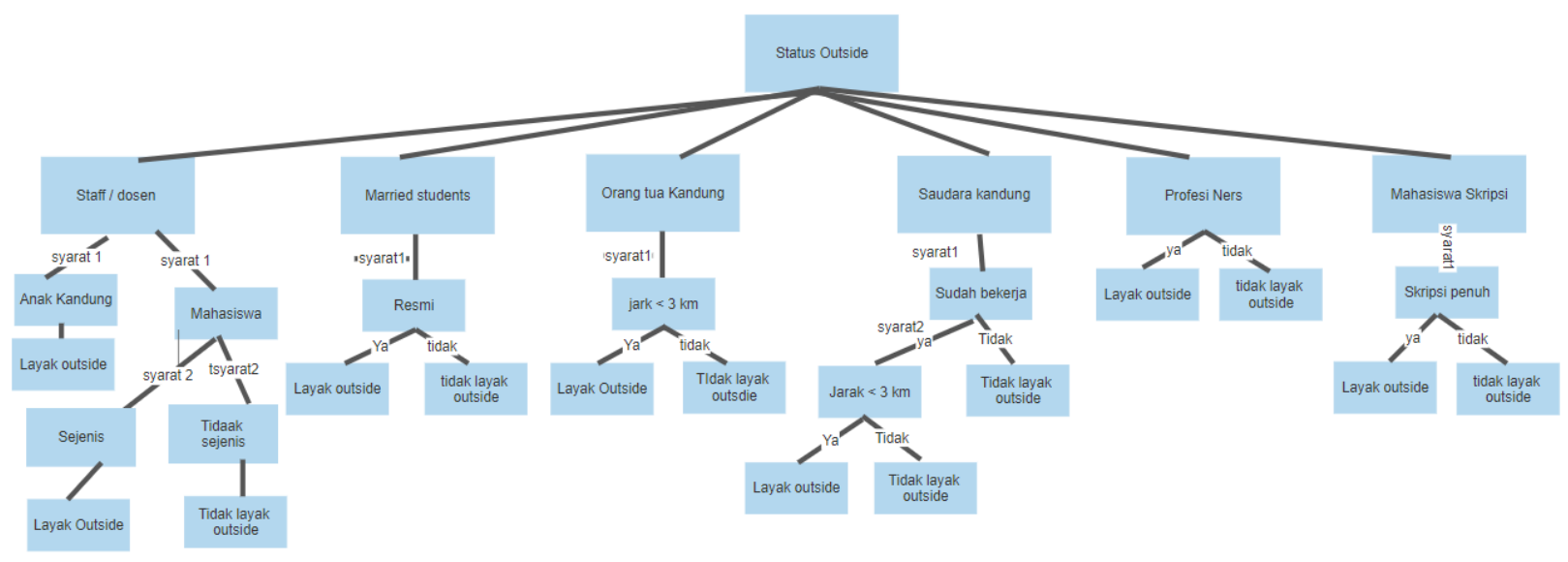

Gambar 9 Diagram Tree seleksi mahasiswa outside

Aturan-aturan yang diperoleh dari pohon keputusan tersebut untuk menentukan kelayakan mahasiswa tinggal di luar asrama adalah sebagai berikut:

Tabel 8 Rule Tinggal di luar asrama

\begin{tabular}{|c|c|}
\hline No & Aturan tinggal di /uar asrama \\
\hline 1 & If status_outside = staff/dosen and syarat1 = anak_kandung then layak outside \\
\hline 2 & If status_outside = staff/dosen and syarat1 = mahasiswa and syarat2 = sejenis then layak_outside \\
\hline 3 & If status_outside $=$ staff $/$ dosen and syarat $1=$ mahasiswa and syarat2 $=$ tidak_sejenis then tidak_layak \\
\hline 4 & If status_outside = married_students and syarat1 = resmi then layak_outside \\
\hline 5 & If status_outside $=$ married_students and syarat $1=$ tidak_resmi then $=$ tidak layak \\
\hline 6 & If status_outside $=$ orang_tua_kandung and syarat1 $=$ jarak $<3 \mathrm{~km}$ then $=$ layak_outside \\
\hline 7 & If status_outside $=$ orang_tua_kandung and syarat $1=$ jarak $>3 \mathrm{~km}$ then $=$ tidak_layak \\
\hline 8 & $\begin{array}{l}\text { IF status_outside = saudara_kandung and syarat1 = sudah_bekerja and syarat2 = jarak }<3 \mathrm{~km} \text { then = } \\
\text { laayak_outside }\end{array}$ \\
\hline 9 & $\begin{array}{l}\text { If status_outside = saudara_kandung and syarat1 = sudah_bekerja and syarat2 =jarak }>3 \text { km then = } \\
\text { tidak_layak }\end{array}$ \\
\hline
\end{tabular}




\begin{tabular}{|l|l|}
\hline $\mathbf{1 0}$ & If status_outside $=$ saudara kandung and syarat1 =belum_bekerja then $=$ tidak_layak \\
\hline $\mathbf{1 1}$ & If status_outside $=$ profesi_ners then $=$ layak_outside \\
\hline $\mathbf{1 2}$ & If status_outside $=$ mahasiswa_skripsi and syarat1 $=$ skripsi penuh then $=$ layak_outside \\
\hline $\mathbf{1 3}$ & If status_outside $=$ mahasiswa_skripsi and syarat1 $=$ tidak_skripsi_penuh then $=$ tidak_layak \\
\hline
\end{tabular}

\section{Perancangan Sistem}

Perancangan sistem diperlukan untuk menggambarkan suatu model aplikasi yang akan digunakan pada saat pengembangan sistem. Dalam hal ini akan digambarkan dalam bentuk use case diagram karena use case diagram adalah diagram yang bekerja dengan cara menjelaskan tipikal interaksi yang ada antara user (pengguna) sebuah sistem dengan sistem itu sendiri. Melalui sebuah cerita yang digambarkan dengan diagram bagaimana sebuah sistem di pakai [12]. Pada gambar 3 ditunjukkan admin dan mahasiswa sebagai aktor yang dapat menggunakan aplikasi. Pada use case diagram dapat dilihat sistem yang dibuat terbagi 2. Untuk admin adalah login, lihat informasi mahasiswa, atur status outside, atur persyaratan 1, atur persyaratan 2, atur hasil seleksi, atur users dan logout, sedangkan untuk mahasiswa adalah login, isi persyaratan outside, lihat informasi hasil seleksi dan logout. Login digunakan untuk masuk ke dalam sistem. Informasi mahasiswa digunakan untuk melihat laporan data mahasiswa. Status outside digunakan untuk menambahkan kategori outside. Persyaratan 1 digunakan untuk menambahkan persyaratan 1. Persyaratan 2 digunakan untuk menambahkan persyaratan lanjutan. Hasil seleksi untuk melihat hasil seleksi dan admin akan memberikan keputusan di halaman tersebut. Users digunakan untuk menambahkan, mengubah atau menghapus pengguna sistem. Pendaftaran outside digunakan mahasiswa untuk mendaftarkan diri. Informasi hasil seleksi digunakan mahasiswa untuk melihat hasil seleksi dan keputusan apakah diterima atau tidak. Logout digunakan untuk keluar dari sistem.

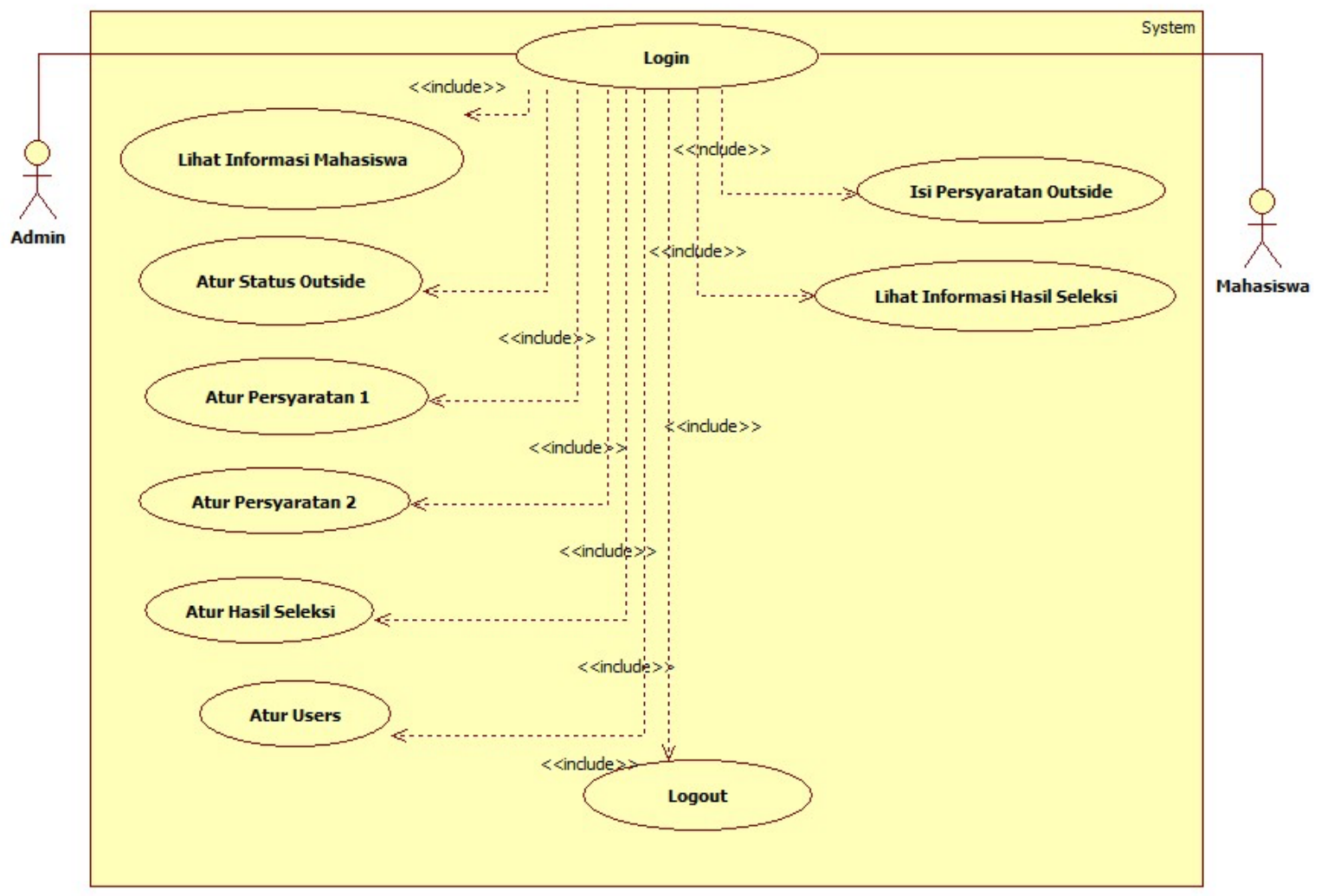

Gambar 10 Use Case Diagram 
Gambar 4 adalah class diagram untuk menggambarkan struktur dan hubungan antar objek-objek yang ada pada sistem, struktur yang meliputi atribut-atribut dan metode-metode yang ada pada masing-masing class [13]. Ada 4 tabel yang digunakan pada penelitian ini yaitu: mhs_outside, Pengguna, tb_status_outside, tb_status_persyaratan, tb_syarat_lanjutan. Tabel mhs_outside digunakan untuk menyimpan data pendaftaran yang diinput oleh mahasiswa. Tabel pengguna untuk menyimpan data pengguna yang bisa login ke dalam aplikasi admin maupun mahasiswa. Tabel tb_status_outside menyimpan data-data status outside dan setiap status outside tersebut memiliki persyaratan yang tersimpan pada tabel tb_status_persyaratan. Tabel tb_status_persyaratan menyimpan persyaratan yang akan digunakan untuk penyeleksian dan beberapa persyaratan tersebut memiliki persyaratan lanjutan yang tersimpan pada tabel tb_syarat_lanjutan. Tabel tb_syarat_lanjutan menyimpan data persyaratan lanjutan yang terhubung sesuai dengan persyaratan sebelumnya dan akan digunakan juga untuk penyeleksian.

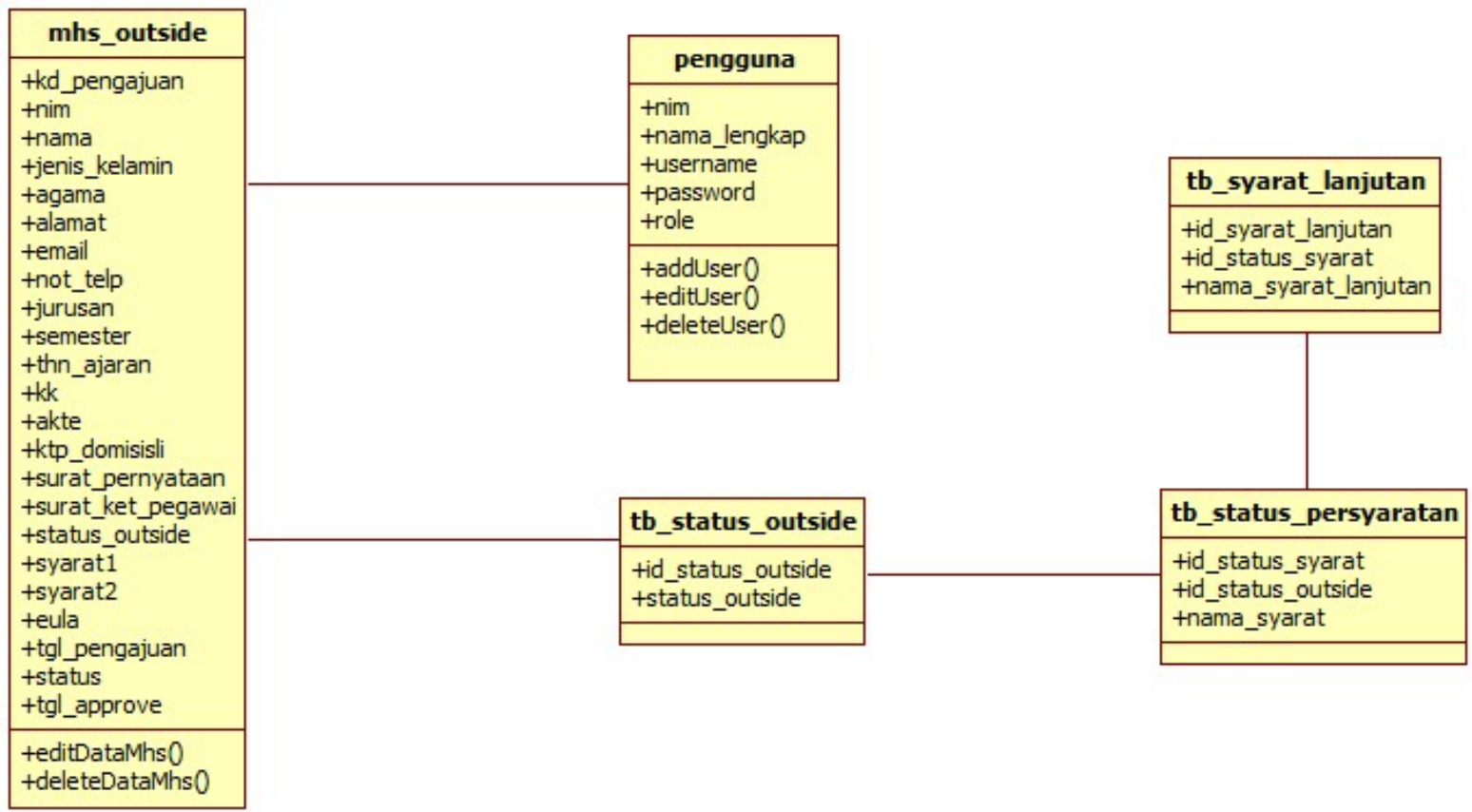

Gambar 11 Class Diagram SPK Untuk Menentukan Kelayakan Mahasiswa Tinggal di Luar Asrama

\section{Kamus Data}

1. Kamus data mhs_outside

Tabel 9 Kamus data Mahasiswa Outside

\begin{tabular}{|l|l|l|l|l|}
\hline Nama Field & Tipe Data & Value & Key & Keterangan \\
\hline kd_pengajuan & Varchar & 255 & PK & Kode pengajuan \\
\hline nim & Int & 10 & FK & Nim pendaftar \\
\hline nama & Varchar & 45 & & Nama pendaftar \\
\hline jenis kelamin & Varchar & 25 & & Jenis kelamin pendaftar \\
\hline agama & Varchar & 25 & & Agama pendaftar \\
\hline alamat & Varchar & 255 & & Alamat pendaftar \\
\hline email & Varchar & 44 & & Email pendaftar \\
\hline no_telp & Int & 15 & & No_telp pendaftar \\
\hline jurusan & Varchar & 35 & & Jurusan \\
\hline semester & Varchar & 255 & & Semester pada saat mendaftar \\
\hline
\end{tabular}




\begin{tabular}{|l|l|l|l|l|}
\hline thn_ajaran & Varchar & 255 & & Tahun ajaran pada saat mendaftar \\
\hline Kk & Mediumlob & & & Scan kartu keluarga \\
\hline Akte & mediumlob & & & Scan akte kelahiran \\
\hline ktp_domisili & Mediumlob & & & Scan ktp atau surat domisili \\
\hline surat_pernyataan & Mediumlob & & & Surat Pernyataan Telah memiliki atau kontrak tempat tinggal \\
\hline surat_ket_pegawai & Mediumlob & & & Scan surat keterangan pegawai \\
\hline status_outside & Varchar & 255 & & Status outside yang akan di pilih \\
\hline syarat1 & Varchar & 255 & & Persyaratan pertama \\
\hline syarat2 & Varchar & 255 & & Persyaratan lanjutan \\
\hline Eula & Varchar & 10 & & Persetujuan mahasiswa \\
\hline tgl_pengajuan & Datetime & & & Tanggal pengajuan pendaftaran \\
\hline status & Varchar & & & Status keputusan \\
\hline tgl_approve & Datetime & & & Tanggal keputusan dibuat \\
\hline
\end{tabular}

2. Kamus data pengguna

Tabel 10 Kamus data pengguna

\begin{tabular}{|l|l|l|l|l|}
\hline Nama Field & Tipe Data & Value & Key & Keterangan \\
\hline Nim & Int & 10 & Pk & Nim pengguna \\
\hline nama_lengkap & Varchar & 89 & & Nama lengkap pengguna \\
\hline username & Varchar & 47 & & Username untuk login \\
\hline password & Varchar & 75 & & Password untuk login \\
\hline Role & Varchar & 11 & & Jenis akun \\
\hline
\end{tabular}

3. Kamus data tb_status_outside

Tabel 11 Kamus data status outside

\begin{tabular}{|l|l|l|l|l|}
\hline Nama Field & Tipe Data & Value & Key & Keterangan \\
\hline id_status_outside & Int & 2 & $\mathrm{Pk}$ & Id status outside \\
\hline status_outside & Varchar & 255 & & Status tempat tinggal \\
\hline
\end{tabular}

4. Kamus data tb_status_persyaratan

Tabel 12 Kamus data persyaratan

\begin{tabular}{|l|l|l|l|l|}
\hline Nama Field & Tipe Data & Value & Key & Keterangan \\
\hline id_status_syarat & Int & 4 & Pk & Id syarat \\
\hline id_status_outside & Int & 2 & Fk & Id status outside \\
\hline nama_syarat & Varchar & 255 & & Nama syarat \\
\hline
\end{tabular}

5. Kamus data tb_syarat_lanjutan

Tabel 13 Kamus data syarat lanjutan

\begin{tabular}{|l|l|l|l|l|}
\hline Nama Field & Tipe Data & Value & Key & Keterangan \\
\hline id_syarat_lanjutan & Int & 8 & $\mathrm{Pk}$ & Id syarat lanjutan \\
\hline id_status_syarat & Int & 4 & $\mathrm{Fk}$ & Id status syarat \\
\hline nama_syarat_lanjutan & Varchar & 255 & & Nama syarat lanjutan \\
\hline
\end{tabular}

\section{Antar Muka Sistem}

Antar muka adalah suatu cara agar pengguna dapat berinteraksi dengan sistem dan dalam bagian ini juga peneliti akan membahas proses pengimplementasian sistem dilakukan. 


\section{Tampilan Halaman Isi persyaratan Outside}

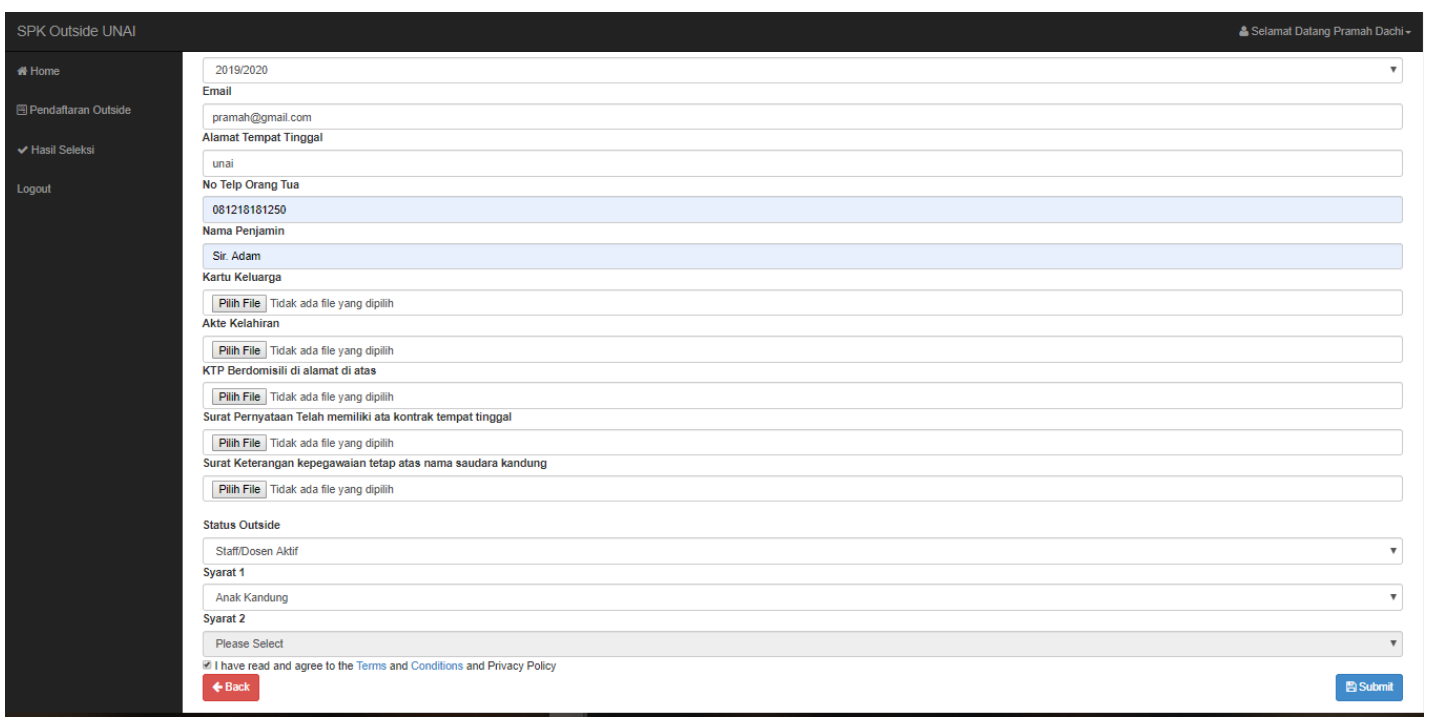

Gambar 12 tampilan halaman isi persyaratan outside

Pada halaman ini user atau mahasiswa akan mendaftar dengan cara mengisi form pendaftaran dan pada bagian bawah form mahasiswa akan menentukan status outside di mana mahasiswa akan tinggal. Pada gambar dicontohkan mahasiswa mendaftarkan diri dengan memilih status outside untuk tinggal Bersama dosen atau staf yang aktif maka persyaratan 1 akan muncul yaitu anak kandung atau mahasiswa jika pendaftar memilih anak kandung maka persyaratan 2 tidak akan muncul tetapi jika mahasiswa tersebut memilih persyaratan 1 adalah mahasiswa maka persyaratan 2 akan muncul yaitu sejenis atau tidak sejenis. Setelah mengisi form mahasiswa juga harus menyetujui semua persyaratan untuk tinggal di luar asrama dengan cara mengisi kotak check-box yang ada di bagian paling bawah form.

\section{Tampilan Halaman Lihat Informasi Mahasiswa}

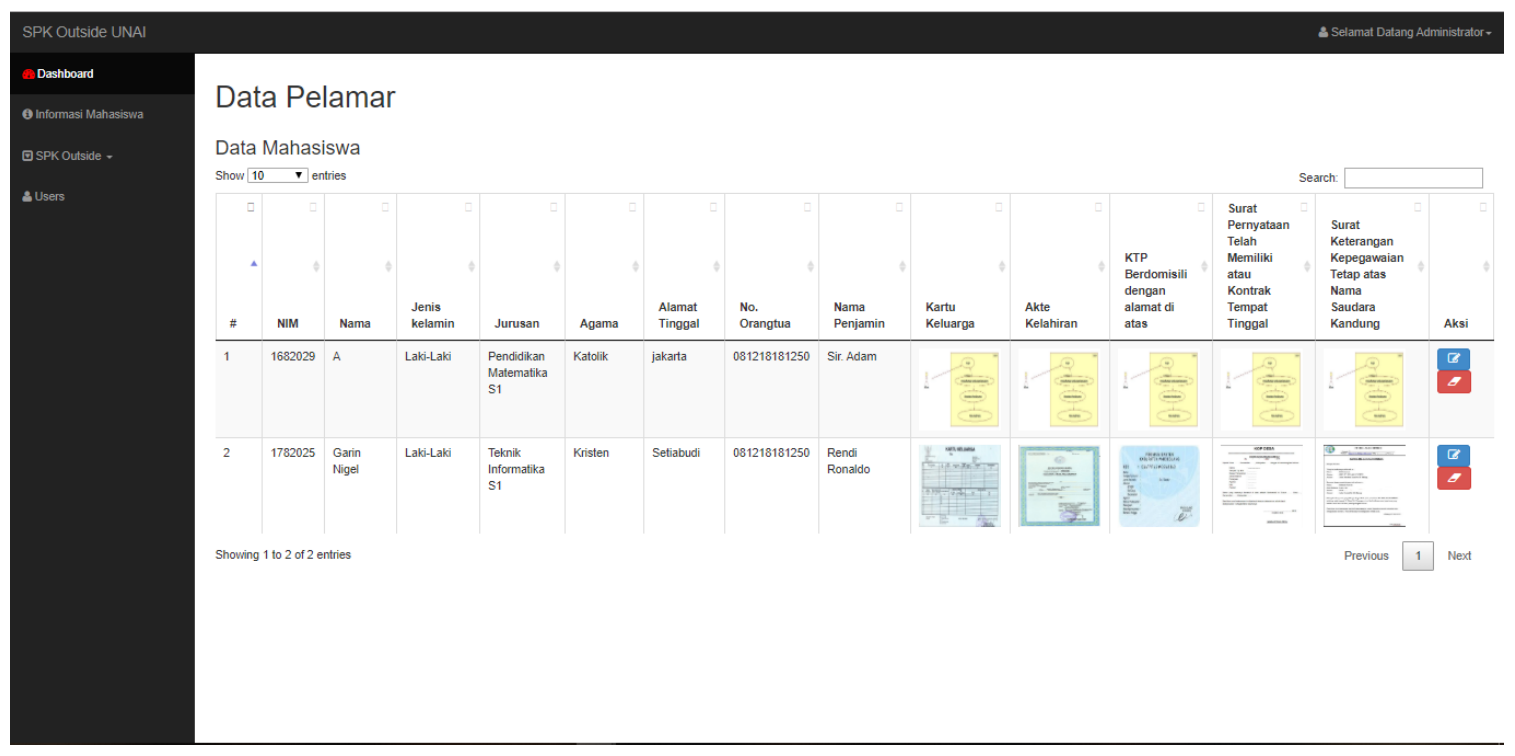

Gambar 13 Tampilan halaman lihat informasi mahasiswa

Pada halaman ini Biro Kemahasiswaan dapat melihat informasi mahasiswa yang mendaftar apakah kelengkapan persyaratan yang dibutuhkan sudah sesuai dengan peraturan sebagai contoh: jika mahasiswa 
mendaftar dan memilih status outside tinggal bersama saudara kandung maka pendaftar harus mengupload berkas seperti kartu tanda penduduk, kartu keluarga, akta kelahiran, surat pernyataan tempat tinggal dan surat keterangan bekerja.

\section{Tampilan Halaman Atur Status Outside}

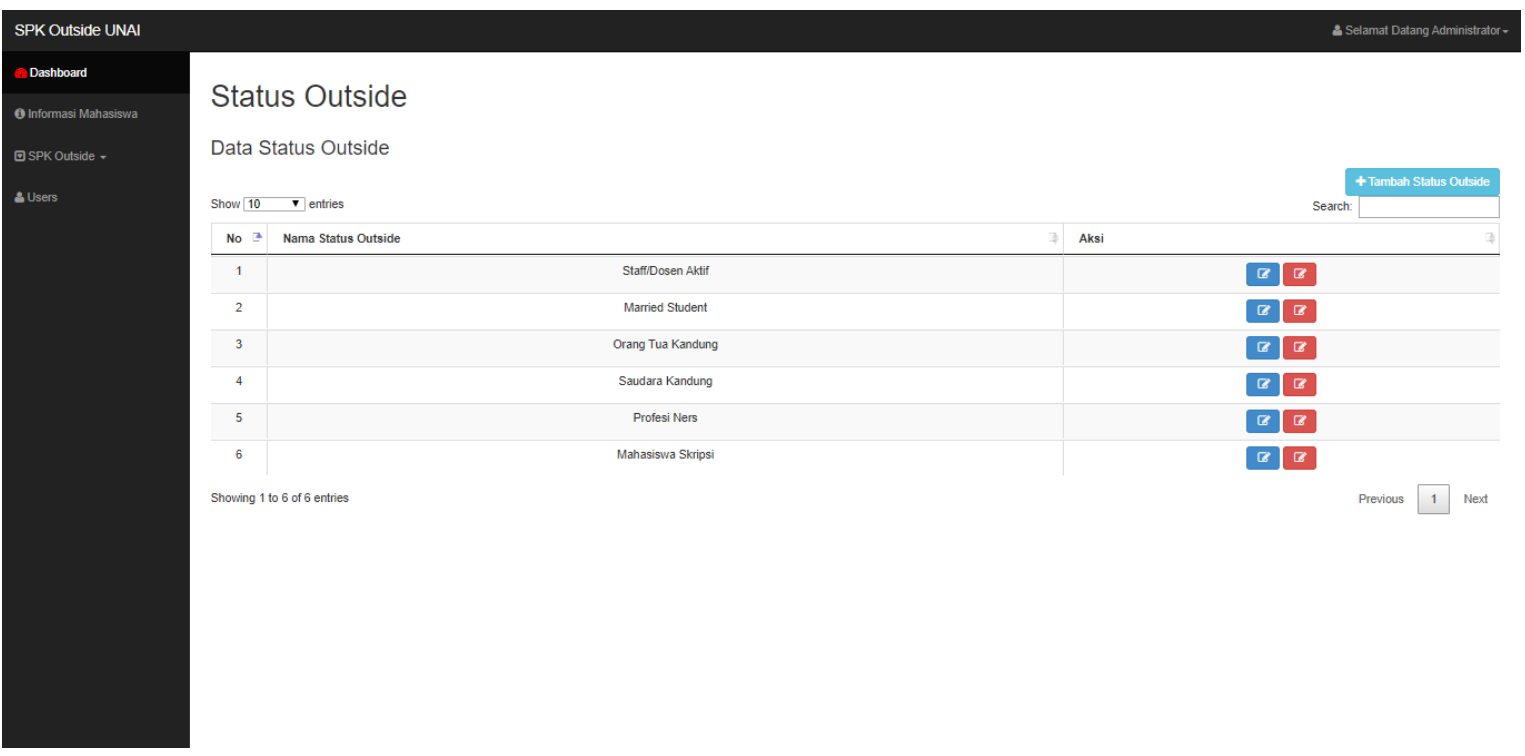

Gambar 14 Tampilan halaman status outside

Pada halaman ini Biro Kemahasiswaan dapat mengatur daftar data status outside. Biro Kemahasiswaan dapat menambahkan status outside dengan cara meng-klik tombol tambah status outside, Biro Kemahasiswaan juga dapat mengubah status outside dengan cara meng-klik tombol edit dan Biro Kemahasiswaan juga dapat menghapus status outside dengan cara meng-klik tombol delete.

\section{Tampilan Halaman Atur Persyaratan 1}

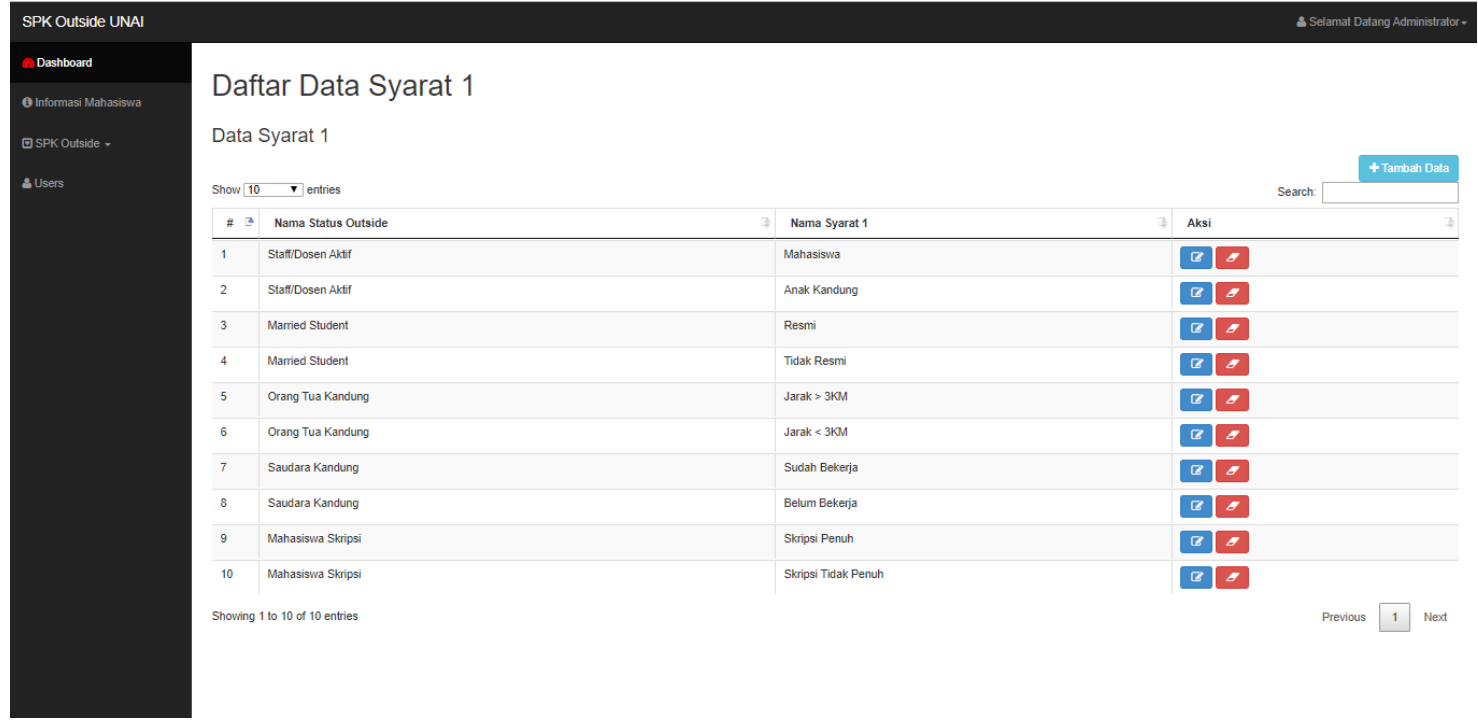

Gambar 15 Tampilan halaman persyaratan 1

Pada halaman ini Biro Kemahasiswaan dapat mengatur data syarat 1. Biro Kemahasiswaan menambahkan data syarat 1 yang sesuai dan saling berhubungan dengan status outside dengan cara 
meng-klik tombol tambah data, Biro Kemahasiswaan juga dapat mengubah daftar data syarat 1 dengan cara meng-klik tombol edit, Biro Kemahasiswaan juga dapat menghapus data syarat 1 dengan cara mengklik tombol delete.

\section{Tampilan Halaman Atur Persyaratan 2}

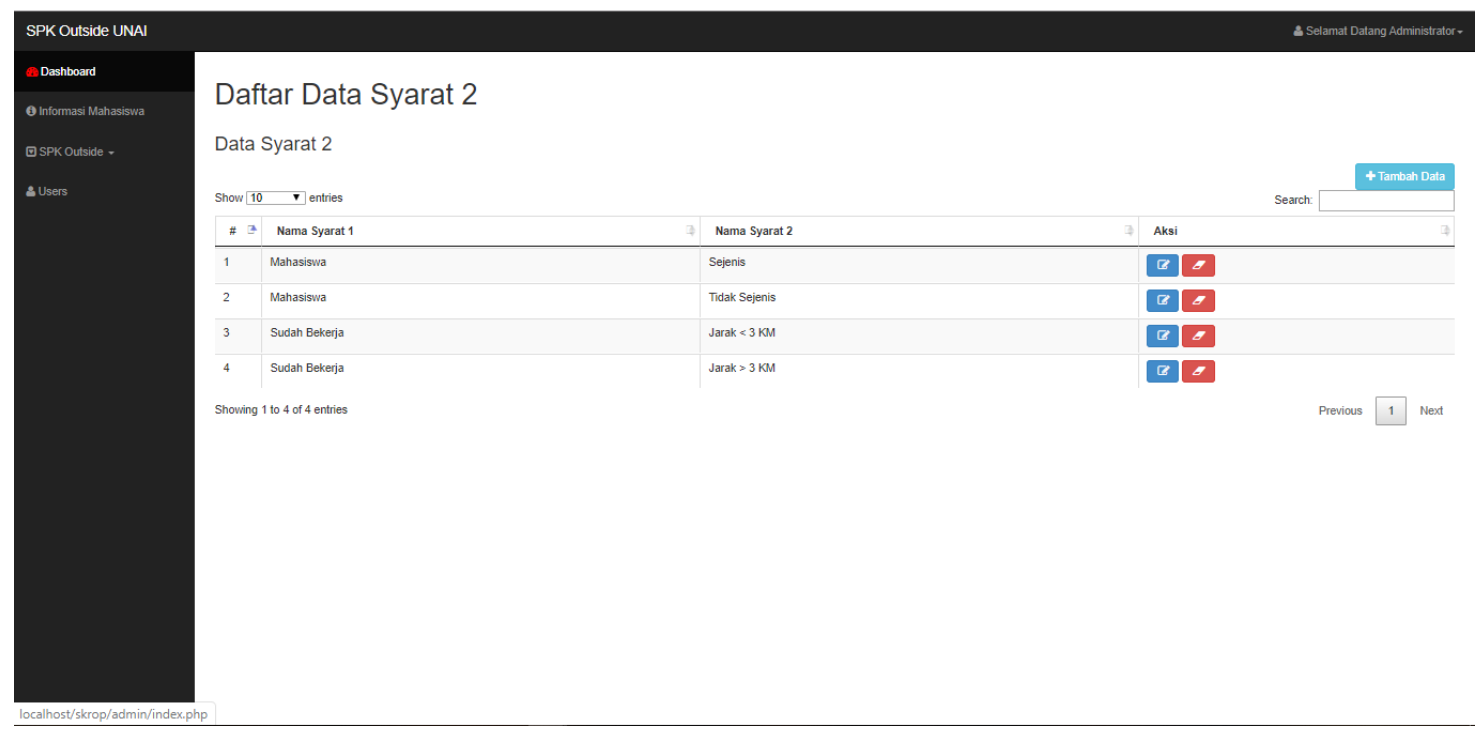

Gambar 16 Tampilan halaman persyaratan 2

Pada halaman ini Biro Kemahasiswaan dapat mengatur data syarat 2. Biro Kemahasiswaan menambahkan data syarat 2 yang sesuai dan saling berhubungan dengan syarat 1 dengan cara meng-klik tombol tambah data, Biro Kemahasiswaan juga dapat mengubah daftar data syarat 1 dengan cara mengklik tombol edit, Biro Kemahasiswaan juga dapat menghapus data syarat 2 dengan cara meng-klik tombol delete.

\section{Tampilan Halaman Hasil Seleksi}

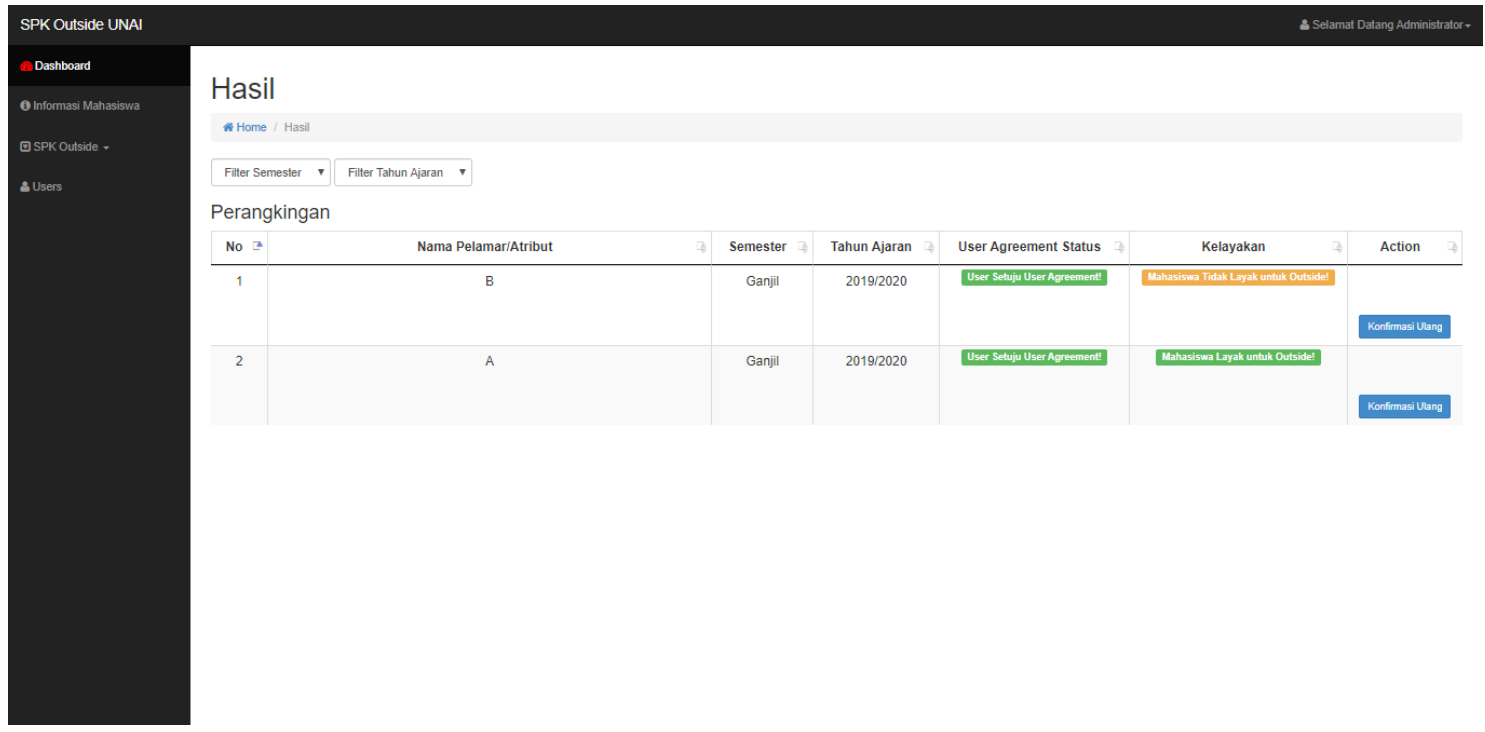

Gambar 17 Tampilan halaman hasil seleksi

Pada tampilan ini Biro Kemahasiswaan dapat melihat saran keputusan yang diberikan sistem sesuai dengan data yang diberikan mahasiswa pada saat mengisi form pendaftaran yang kemudian di proses 
menjadi hasil saran keputusan apakah mahasiswa yang mendaftar tersebut layak atau tidak layak untuk tinggal di luar asrama sebagai contoh: Mahasiswa A mendaftarkan diri dengan status outside tinggal bersama dosen atau staf aktif dan memilih persyaratan 1 sebagai anak kandung, maka sistem akan menyatakan bahwa mahasiswa A layak untuk tinggal di luar asrama. Tetapi jika seperti mahasiswa B yang memilih status outside tinggal bersama saudara kandung lalu memilih syarat 1 belum bekerja, maka sistem akan menyatakan bahwa mahasiswa B tidak layak untuk tinggal di luar asrama karena sesuai dengan peraturan yang dikeluarkan Biro Kemahasiswaan bahwa mahasiswa yang ingin tinggal bersama saudara kandung maka saudara kandung tersebut harus sudah bekerja. Pada halaman ini Biro Kemahasiswaan juga dapat melihat bahwa mahasiswa setuju untuk mengikuti semua peraturan yang ada untuk tinggal di luar asrama. Setelah melihat saran keputusan yang diberikan sistem, Biro Kemahasiswaan harus mengkonfirmasi keputusan akhir apakah mahasiswa tersebut layak tinggal di luar asrama atau tidak layak untuk tinggal di luar asrama dengan cara meng-klik tombol konfirmasi dan memilih approve atau rejected, Biro Kemahasiswaan juga dapat mengubah keputusan jika sewaktu-waktu pelamar melakukan pelanggaran dengan cara meng-klik tombol konfirmasi ulang.

\section{Tampilan Halaman Hasil Seleksi}

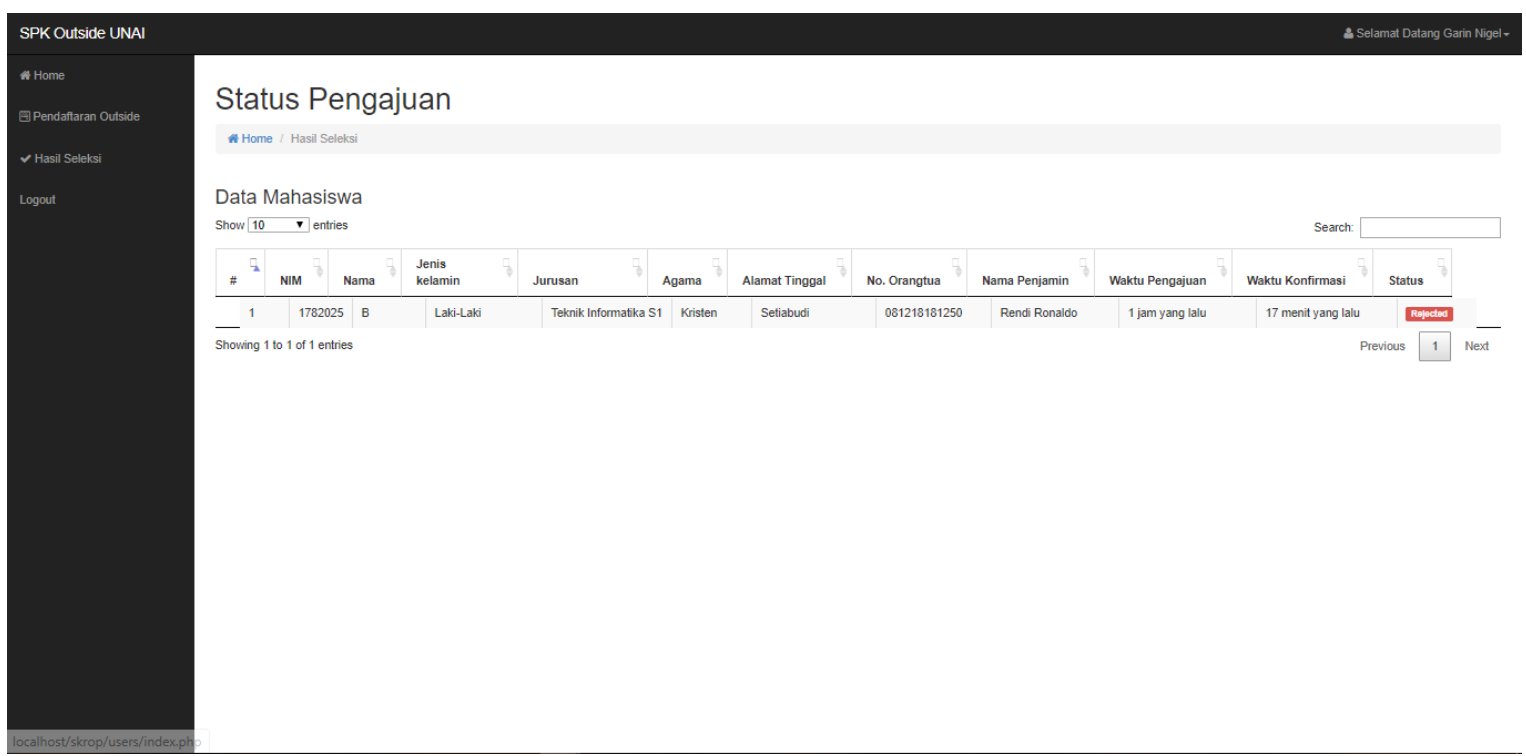

Gambar 18 Tampilan halaman lihat informasi hasil seleksi ditolak

Pada halaman ini mahasiswa dapat melihat status pendaftaran yang sebelumnya sudah diisi, pada halaman ini mahasiswa jadi mengetahui apakah mahasiswa yang sudah mendaftar tersebut diizinkan untuk tinggal di luar asrama atau tidak diizinkan untuk tinggal di luar asrama. Sebagai contoh mahasiswa B diputuskan tidak layak untuk tinggal di luar asrama dengan tanda rejected (gambar 11) dan mahasiswa A diputuskan layak untuk tinggal di luar asrama dengan tanda approve (gambar 12) 


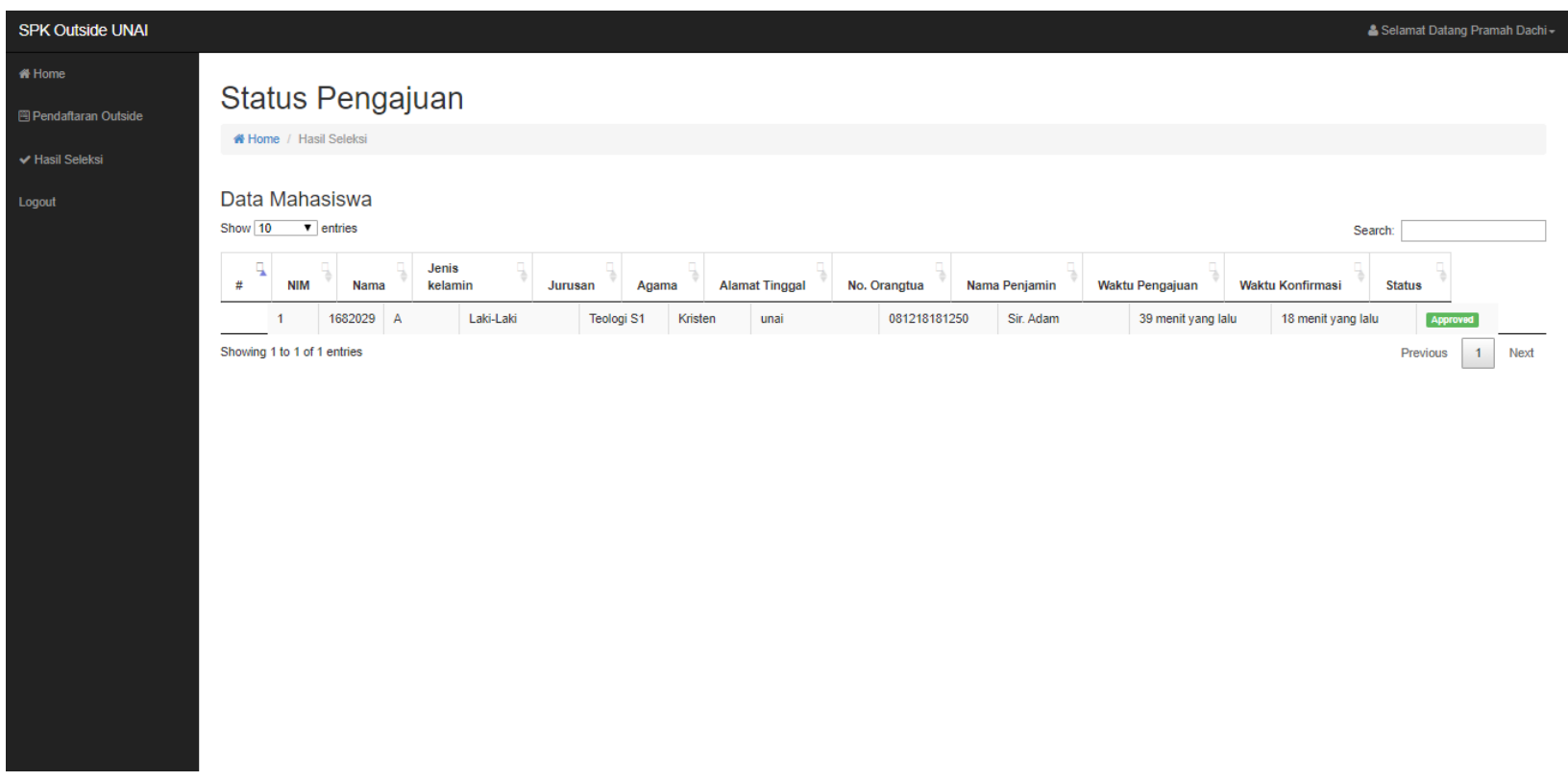

Gambar 19 Tampilan halaman lihat informasi hasil seleksi diterima

\section{Tampilan Halaman Users}

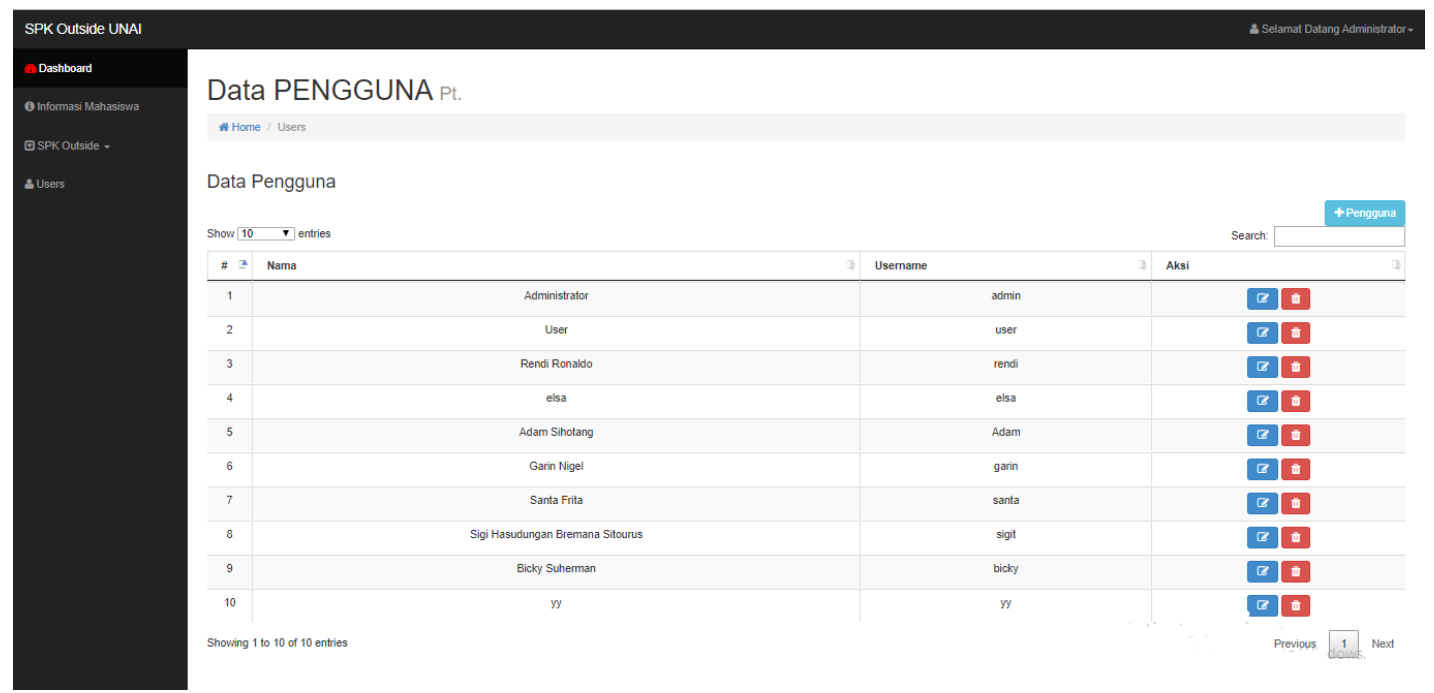

Gambar 20 Tampilan halaman users

Pada halaman ini Biro Kemahasiswaan dapat melihat daftar pengguna sistem tersebut, Biro Kemahasiswaan juga dapat menambah pengguna dari sistem tersebut dengan cara meng-klik tombol tambah pengguna, Biro Kemahasiswaan juga dapat mengubah pengguna Dengan cara meng-klik tombol edit, Biro Kemahasiswaan juga dapat menghapus pengguna dengan cara meng-klik tombol delete.

\section{Kesimpulan}

Setelah dilakukan Pengujian sistem maka diperoleh kesimpulan sebagai berikut:

1. Sistem yang sudah dirancang dapat melakukan penyeleksian mahasiswa yang ingin tinggal di luar asrama secara komputerisasi. 
2. Metode Forward Chaining mampu melakukan pengambilan keputusan dan dapat digunakan oleh Biro Kemahasiswaan untuk membantu pada saat proses penyeleksian.

3. Sistem Mampu memberikan pelaporan tentang informasi Mahasiswa tinggal di luar asrama secara komputerisasi.

Adapun saran-saran yang berkaitan dengan pengembangan dari sistem yang telah peneliti buat, yaitu:

1. Pengembangan sistem ini selanjutnya diharapkan dapat menggunakan metode lain seperti Analitycal Hierarchy Process (AHP) dan Technique For Others Preference by Similarity to Ideal Solution (TOPSIS) agar dapat dilakukan perbandingan keefektifan proses dalam pengambilan keputusan.

2. Aplikasi dapat dikembangkan menjadi lebih dinamis dan variatif

\section{Referensi}

[1] A. Rizkiani, "PENGARUH SISTEM BOARDING SCHOOL TERHADAP PEMBENTUKAN KARAKTER PESERTA DIDIK," Jurnal Pendidikan Universitas Garut, vol. 6, pp. 10-18, 2012.

[2] E. Y. Anggraeni and R. Irviani, Pengantar Sistem Informasi, Yogyakarta: ANDI, 2017.

[3] D. N. Handayani, F. . N. Hakim and A. Solechan, "SISTEM PENDUKUNG KEPUTUSAN UNTUK PEMILIHAN JURUSAN MENGGUNAKAN FUZZY MULTIPLE ATRIBUTE DECISION MAKING DENGAN METODE SIMPLE ADDITIVE WEIGHTING STUDI KASUS PADA SMA ISLAM SULTAN AGUNG 1 SEMARANG," JURNAL TRANSFORMATIKA, vol. 11, pp. 69-78, 2014.

[4] R. Afnur, T. Sriwahyuni and A. Hadi, "RANCANG BANGUN APLIKASI SISTEM PAKAR UNTUK DIAGNOSIS KERUSAKAN SEPEDA MOTOR MATIC MENGGUNAKAN METODE FORWARD CHAINING," Jurnal Vokasional Teknik Elektronika \& Informatika, vol. 4 no 2, pp. 75-84, 2016.

[5] N. Y. S. Munti and F. A. Effindri , "Perancangan Aplikasi Sistem Pakar Diagnosa Penyakit Ginekologi Menggunakan Metode Forward Chaining Berbasis Web Mobile," Jurnal Media Infotama, vol. 13 no 2, pp. 67-72, 2017.

[6] D. wahyu and M. R. Widyanto, "STUDI PERBANDINGAN POHON KEPUTUSAN DAN POHON KEPUTUSAN PADA KLASIFIKASI PENUTUP LAHAN," Jurnal IImiah KURSOR, vol. 6, pp. 1-10, 2011.

[7] S. "file.upi.edu," [Online]. Available: http:// file.upi.edu/Direktori/FIP/JUR._ADMINISTRASI_PENDIDIKAN/196807291998021-

SURYADI/Model_dan_keterampilan_pengambilan_keputusan.pdf. [Accessed 299 2019].

[8] M. A. Sembiring, "PENERAPAN METODE DECISSION TREE ALGORITMA C45 UNTUK MEMPREDIKSI HASIL BELAJAR MAHASISWA BERDASARKAN RIWAYAT AKADEMIK," JURTEKSI, vol. 3, pp. 1-10, 2016.

[9] M. Yunus and S. Setyowibowo, "APLIKASI SISTEM PENDUKUNG KEPUTUSAN DIAGNOSA PENYAKIT PARUPARU DENGAN METODE FORWARD CHAINING," Jurnal Teknologi Informasi , vol. 2, pp. 95$114,2011$.

[10] I. G. Sandika, A. E. Permanasari and S. Sumaryono, "PENENTUAN KARAKTERISTIK PENGGUNA SEBAGAI PENDUKUNG KEPUTUSAN DALAM MEMILIH SMARTPHONE MENGGUNAKAN FORWARD CHAINING," in SNATIF, Kudus, 2014.

[11] M. G. Rohman, "Sistem Pendukung Keputusan Pemilihan Tanaman Pangan Menggunakan Metode Forward Chaining," Jurnal TeknikA, vol. 8, pp. 819-825, 2016. 
[12] S. R. Wurdianarto, . S. Novianto and U. Rosyidah, "PERBANDINGAN EUCLIDEAN DISTANCE DENGAN CANBERRA DISTANCE PADA FACE RECOGNITION," Techno.COM, vol. 13, pp. 31-37, 2014.

[13] R. Panuntun, A. F. Rochim and K. T. Martono, "Perancangan Papan Informasi Digital Berbasis Web Pada Raspberry pi," Jurnal Teknologi dan Sistem Komputer, vol. 3 no 2, pp. 192-197, 2015.

[14] S. D. Anggadini, "ANALISIS SISTEM INFORMASI MANAJEMEN BERBASIS KOMPUTER DALAM PROSES PENGAMBILAN KEPUTUSAN," Majalah IImiah UNIKOM, vol. 2 no 11, pp. 176-187, 2013.

[15] I. A. M, F. Marisa and I. D. WIjaya, "Information Technology and Computer Science (JOINTECS) Vol. 1, No. 2, Januari 2017 1," Journal of Information Technology and Computer Science (JOINTECS), vol. 1 no 2, pp. 1-5, 2017.

[16] T. Mufizar, "Sistem Pendukung Keputusan Pemilihan Dosen Berprestasi Di STMIK Tasikmalaya Menggunakan Metode Simple Additive Weighting (SAW," CSRID Journal, vol. 7 no 3, pp. 155-166, 2015.

[17] A. S. Putra, D. R. Aryanti and I. Hartati, "Metode SAW (Simple Additive Weighting) sebagai Sistem Pendukung Keputusan Guru Berprestasi ( Studi Kasus : SMK Global Surya)," Seminar Nasional Teknologi dan Bisnis, pp. 85-97, 2018.

[18] A. Y. R, M. I. Ukkas and M. I. Amal, "MEMBANGUN APLIKASI PERMAINAN "HANOMAN N' FRIENDS"," SNITT- Politeknik Negeri Balikpapan, pp. 217-223, 2017. 